\title{
Prey-capture efficiency between juveniles and adults, feeding habitat and abundance of Wattled Jacana foragers in northern Pantanal, Mato Grosso state, Brazil
}

\author{
Forti, LR. ${ }^{a, b *}$ and Nóbrega, PFA. ${ }^{a}$ \\ aPrograma de Pós-Graduação em Ecologia e Conservação da Biodiversidade, Instituto de Biociências, \\ Universidade Federal de Mato Grosso - UFMT, Av. Fernando Corrêa da Costa, \\ CEP 78060-900, Boa Esperança, Cuiabá, MT, Brazil \\ 'Programa Interunidades de Pós-Graduação em Ecologia Aplicada, Escola Superior de Agricultura "Luiz de Queiroz", \\ Universidade de São Paulo - USP, Av. Pádua Dias, 11, CP 9, CEP 13418-900, Piracicaba, SP, Brazil \\ *e-mail: lucas_forti@yahoo.com.br \\ Received March 24, 2011 - Accepted July 29, 2011 - Distributed May 31, 2012
}

(With 3 figures)

\begin{abstract}
The choice of foraging strategies implies an attempt at gaining energy by predators. Supposedly, the difference in employing the "sit and wait" or "active foraging" behavior lays in hunter skills, experience and the kind of prey consumed. With the hypothesis that "active foraging" demands no learning, in this study we compared the prey capture efficiency among Wattled Jacana juveniles and adults, and also present descriptive information about feeding habitat and the abundance variation of foragers throughout the day in the northern Pantanal. Prey capture efficiency did not differ significantly among juveniles and adults, corroborating our initial hypothesis that "active foraging" is an instinctive behavior and demands no experience to be effective. However, future work is necessary to compare the energetic quality of consumed items by juveniles and adults, searching for differences explained by adults' experience. Foraging individuals were found at an average distance of $14 \mathrm{~m}$ ranging from 2 to $42 \mathrm{~m}$ ) from the margin of the sampled swamps, however $64 \%$ of the foragers were found closer to the margins. The average depth of foraging sites was $17 \mathrm{~cm}$, ranging from 5 to $40 \mathrm{~cm}$, although no preference for specific classes of depth was found ( $p>0,05)$. Despite the accepted general pattern of birds being more active in the early morning, the largest number of individuals foraging was observed between 11:00 and 12:00 AM, but no significant difference was found in the abundance of foraging individuals among different periods of the day. Factors, which were not analyzed, such as food availability and presence of competitors and predators need to be studied to reveal the main factors of the spatial and temporal distribution of the Wattled Jacana.
\end{abstract}

Keywords: foraging strategies, feeding behavior, Jacana jacana, spatial and temporal distribution, Pantanal.

\section{Eficiência de captura de presas entre jovens e adultos, habitat de alimentação e abundância de Jaçanãs forrageadores no Pantanal Norte, Mato Grosso, Brasil}

\begin{abstract}
Resumo
A escolha de uma estratégia de forrageamento implica em uma tentativa de maximizar o ganho energético por predadores. Supostamente, a diferença em empregar o comportamento "senta e espera" ou o "forrageamento ativo" jaz sobre a habilidade de caça, a experiência e o tipo de presa consumida. A partir da hipótese de que o "forrageamento ativo" não demanda aprendizado, neste trabalho é comparada a eficiência de captura de presas entre jovens e adultos de Jaçanãs forrageadores, além de serem apresentadas informações descritivas sobre o habitat de alimentação e a variação na abundância de forrageadores ao longo do dia no Pantanal Norte. Os itens consumidos foram contabilizados para estimativas da eficiência de captura de presas, a qual não diferiu significativamente entre as classes etárias analisadas; corroborou-se, dessa forma, a hipótese inicial de que o "forrageamento ativo" é um comportamento instintivo e não demanda experiência para ter eficiência. No entanto, ainda é necessária pesquisa mais detalhada, comparando-se qualitativamente a dieta de jovens e adultos, com a intenção de testar se a experiência de adultos implica no consumo de presas com mais energia disponível. Os indivíduos forragearam, em média, a $14 \mathrm{~m}$ (amplitude de 2 a $42 \mathrm{~m}$ ) de distância da margem dos brejos e lagoas amostradas; porém, 64\% dos indivíduos avistados forrageavam em distâncias mais próximas da margem. A profundidade média dos locais de forrageio foi de $17 \mathrm{~cm}$, com amplitude variando de 5 a $40 \mathrm{~cm}$, não havendo preferência dos forrageadores por classes de profundidade específicas ( $p>0,05)$. Apesar do padrão esperado para aves, segundo o qual a maior atividade ocorre nos momentos iniciais da manhã, o maior número de indivíduos forrageando foi observado entre 11:00 e 12:00 horas; porém, não houve diferença significativa na abundância de indivíduos forrageadores entre diferentes períodos do dia. Outros fatores, não analisados, tais como a disponibilidade alimentar e a presença de competidores e predadores, precisam ser estudados para se revelarem os principais determinantes da distribuição espacial e temporal dos Jaçanãs no Pantanal.
\end{abstract}

Palavras-chave: forrageamento, comportamento alimentar, Jacana jaçanã, distribuição espaço-temporal, Pantanal. 


\section{Introduction}

Prey-capture behavior demands high energy costs, as well as the ability to carry out successful captures (Valle, 2006). According to optimal foraging theory (MacArthur and Pianka, 1966), the animals choose between alternative foraging strategies to maximize their energy gain, balancing the time spent handling and searching for food with the quantity of energy (calories) of the resource. Thus, foraging activity should be maintained until the energy gain, from the intake of food items, is larger than the energy spent on acquiring them (MacArthur and Pianka, 1966).

Some bird species, such as Phalacrocorax brasilianus (Gmelin, 1789) (Morrison et al., 1978), Leucophaeus atricilla (Linnaeus, 1758) (Burger and Gochfeld, 1983) and Sturnus vulgaris (Linnaeus, 1758) (Stevens, 1985) may show ontogenetic changes in diet composition. This characteristic has been considered an evolutionary adaptation to avoid intra-specific competition (Werner and Gilliam, 1984). However, it is possible that this factor is coupled with the inability juveniles have in recognizing and capturing prey, thus attacking easier prey of less energetic value (Morrison et al., 1978).

Prey capture efficiency is directly related to the foraging tactic used by the species to obtain food resources (Morrison et al., 1978). The gain in experience makes foraging more efficient (Burger and Gochfeld, 1983). The measure of foraging effectiveness can be the capture rate of prey, defined as the number of prey obtained in a given time interval (Burger and Gochfeld, 1983).

Similar to ontogenetic change in diet composition, differences in foraging success between age groups have also been attributed to the difficulty juveniles have in finding or recognizing potential prey and the lack of experience in capturing and manipulating their victim (Morrison et al., 1978; Burger and Gochfeld, 1983; Vanderhoff and Eason, 2008). Therefore, in many species of birds with well developed parental care, it is common to see juveniles and adults foraging together during the final period of the reproductive cycle, so that the juveniles may learn the foraging techniques (Lima et al., 2008). However, those species that are active foragers and are not "sit and wait" foragers get their food in a more instinctive way, probably not requiring experience and skill to be effective. Possibly, many of these species gather in foraging flocks as a defensive strategy, reducing individual exposure and the chance of being preyed upon (Clark and Mangel, 1986). Moreover, Robinson and Holmes (1982) while studying birds of forest environments, found that structural characteristics of the foraging environment, as well as the capture tactics, can also determine which and how many prey are captured. The structure of the foraging environment also determines the choice of where (spatial distribution) and when (temporal distribution) will forage (Moreno et al., 2005).

Jacana jacana (Linnaeus, 1766) is a water bird species with a slender lightweight body, member of the family Jacanidae, occurring in Brazil and widely distributed throughout the Americas (Stotz et al., 1996). Despite the fact that the plumage is very similar between sexes, females are much larger than males (Sick, 1997; Emlen and Wrege, 2004b). Only juveniles are distinguishable by plumage coloration (Ferreira, 1984; Nunes and Piratelli, 2005; Osborne and Bourne, 1977; Sick, 1997). These birds are territorial, and live in pairs or polyandrous harems (Sick, 1997; Emlen and Wrege, 2004a; Sigrist, 2006). Although precocial, the chicks stay close to parents for about two months, taking the opportunity to learn survival techniques with them. This species is considered omnivorous (Nunes and Piratelli, 2005), and uses active foraging behavior to capture prey on margins of swamp habitats (Sick, 1997; Antas, 2004; Nunes and Piratelli, 2005).

The aim of this study was to observe the differences in prey-capture efficiency between juveniles and adults of Jacana jacana and also to describe the feeding habitat and the change in foraging abundance throughout the day.

\section{Material and Methods}

\subsection{Study area}

Data collection took place in Nossa Senhora do Livramento, state of Mato Grosso, midwestern Brazil, between July 30 and August 2, 2007. The area is located in the northern Pantanal ( $16^{\circ} 22^{\prime} 0.4$ " S and 56 17 ' 56.6" W), between the rivers Bento Gomes and Cuiabá, which are subject to seasonal flooding, attracting numerous waterfowl including Jacana jacana. The observation points are characterized by flooded areas, containing floating vegetation (Eichornea sp.) and native grassland on the edge of lakes, typical places for foraging and nesting of J. jacana (Sick, 1997; Antas, 2004).

\subsection{Foraging}

A total of 24 individuals were observed foraging, 12 adults and 12 juveniles, distinguishable by their plumage coloration. To reduce the risk of double counting the same individual, due to the difficulty of capturing and marking, we spread the sampling varying the places of data collection, never collecting in the same observation point. The number of prey caught in 10 minutes was recorded for each individual, thus obtaining the prey-capture efficiency. Bushnell and Pentax binoculars $(10 \times$ and $8 \times)$ were used to observe prey-capture behavior. The sampled was performed in the morning, between 06:00 and 12:00 AM and in the afternoon, between 4:00 and 6:00 PM, for three consecutive days. To describe the feeding habitat, based on 25 foraging individuals, data were collected referring to the distance from the nearest edge and the water depth. We used a $1 \mathrm{~m}$ metal ruler to measure depth and counted the number of steps to estimate the approximate distance from the edge.

We counted the number of individuals foraging during three periods: morning (6:00-8:00 AM), noon (10:0012:00 AM) and afternoon (4:00-6:00 PM) in order to find out whether there is a difference in forager abundance at different times of the day. These data were collected using a $220 \mathrm{~m}$ transect in two of the four swamps used in the study. 


\subsection{Data analysis}

The prey-capture efficiency was determined by the Equation 1:

$\mathrm{CE}=\mathrm{NP} / \mathrm{T}$

where NP = "number of prey caught", T = "time of observation" in minutes and CE = "capture efficiency".

The comparison of prey-capture efficiency between juveniles and adults was made using the unpaired $t$-test, adopting a significance level of 0.05 .

To assess the spatial distribution pattern of foragers, we prepared histograms using depth measurements and distance from the edge. Scott's rule was used to find the number of classes shown in the histograms (Scott, 1979): $\mathrm{k}=3.5 . \mathrm{s} . \mathrm{n}^{-1 / 3}$, where ' $\mathrm{k}$ ' is the number of Scott classes, ' $n$ ' is the number of observations and ' $\mathrm{s}$ ' is the standard deviation of the sample. The range was calculated based on the overall amplitude of the data and the number of classes generated by Scott's (k) formula. We also performed an adjustment analysis $\left(\mathrm{x}^{2}\right)$ to assess whether the foragers showed a preference for any depth, with a significance level of 0.05 .

The forager abundance throughout the day was obtained by the number of individuals observed along the transects. Considering that the middle of the day would have a higher solar incidence with greater heat intensity (Land, 1963; Leck, 1969), we hypothesized that individuals would be at a lower abundance during this period. Thus, the abundance of individuals was compared for three periods, 6:00-8:00 AM, 10:00-12:00 AM and 4:00-6:00 PM, and at two different locations using a factorial analysis of variance, adopting a significance level of 0.05 .

\section{Results}

The prey-capture efficiency did not differ between juveniles and adults $(t=0.54, \mathrm{df}=22, \mathrm{p}>0.05)$ (Figure 1$)$. For 10 minutes the mean number of prey captured was $23.6( \pm 4.6)$ by the adults and $26( \pm 8.1)$ by the juveniles.

Foragers were present in macrophyte banks of lakes or flooded areas. They occurred more frequently in middepth ranges, mostly between 16.5 and $19.8 \mathrm{~cm}$ (mean $17 \pm 8.7 \mathrm{~cm}$ ) and were largely distributed between 4.9 and $7.8 \mathrm{~m}$ from the edge (mean $14 \pm 11 \mathrm{~m}$ ). The adjustment test $\left(\mathrm{x}^{2}\right)$ showed no depth preference among foragers $(\mathrm{p}>0.05)$, showing a normal frequency curve (Figure 2). However, foragers were more abundant in the distance classes closer to the edges of the swamps (Figure 3).

During the five censuses carried out at different times (morning, noon and afternoon), we observed the highest abundance of foragers in the middle of the day, when we recorded 14 individuals foraging in the $220 \mathrm{~m}$ transect. However, no significant difference in foraging abundance was observed between the times of day and study sites (Table 1).

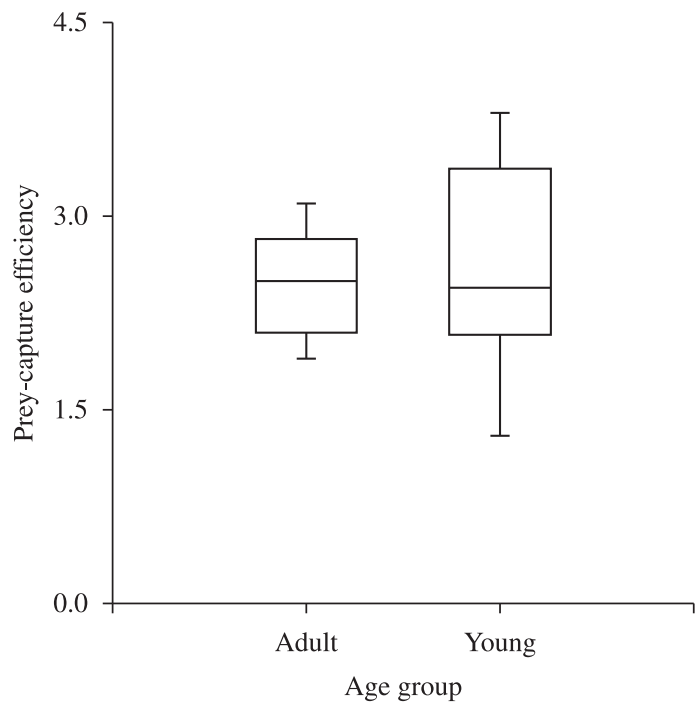

Figure 1. Prey capture frequency per minute by adults and juveniles of the Wattled Jacana from Northern Pantanal.

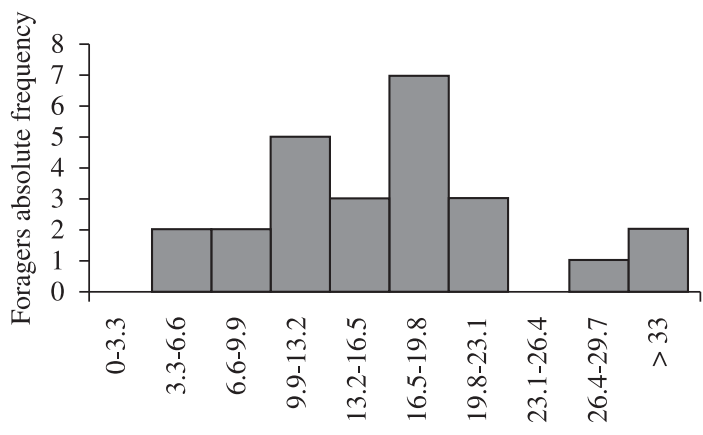

Lakes depth class $(\mathrm{cm})$

Figure 2. Numbers of foraging individuals of the Wattled Jacana per depth class on the four collection sites $(n=25)$ in Northern Pantanal.

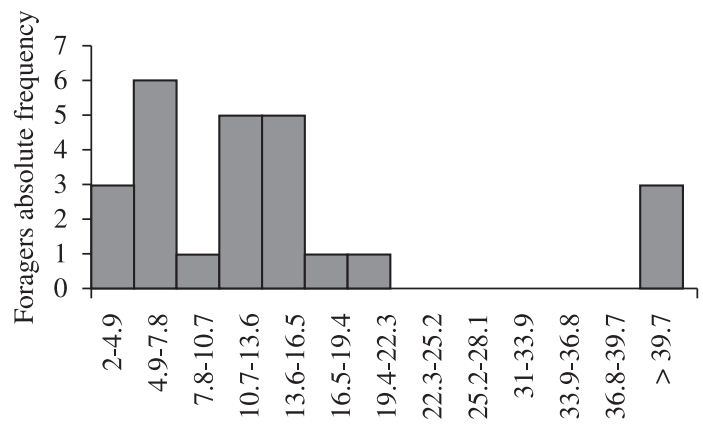

Lakes edge distance class $(\mathrm{m})$

Figure 3. Numbers of foraging individuals of the Wattled Jacana per edge distance class on the four collection sites $(\mathrm{n}=25)$ in Northern Pantanal. 
Table 1. Factorial analysis of variance, comparing the abundance of individuals of the Wattled Jacana during three periods of the day (morning, noon, afternoon) and at two observation sites.

\begin{tabular}{ccccc}
\hline Source of variation & Degrees of freedom & Mean square & F value & p value \\
\hline Local & 1 & 0.00004224 & 0.12 & 0.733 \\
Period & 2 & 0.00000549 & 0.02 & 0.984 \\
Interaction & 2 & 0.00020062 & 0.59 & 0.576 \\
Residual & 9 & 0.00034219 & - & - \\
Total & 14 & - & - & - \\
\hline
\end{tabular}

\section{Discussion}

The similarity found in the prey-capture efficiency between juveniles and adults is probably due to the foraging tactics used by the individuals (active foraging) (Nunes and Piratelli, 2005). This tactic has a lower energy cost when compared to the strategies that require aerial maneuvers (Remsen and Robinson, 1990), and does not involve the acquisition of experience by the juveniles since it is a more instinctive than learned tactic. This is different from what occurs, for example, with the snail kite (Rosthramus sociabilis) (Vieillot, 1817), the swallowtailed hawk (Elanoides forficatus) (Linnaeus, 1758) and frugivorous birds (Vanderhoff and Eason, 2008). The tactics employed to capture food in these cases involve more skills that are acquired during the development and learning of the juveniles with their parents (Azevedo and Di-Bernardo, 2005; Vanderhoff and Eason, 2008).

In addition to the active foraging capture tactics employed by the Wattled Jacana, in Três Lagoas, Mato Grosso do Sul state Nunes and Piratelli (2005) reported the use of "sit-and-wait" strategies by the same species when capturing insect larvae. Martins and Donatelli (2001) and Azevedo et al. (2006) recorded the same "sit-and-wait" capture tactics for Guira guira (Guira Cuckoo) (Gmelin, 1788), Harpagus diodon (Rufous-thighed Kite) (Temminck, 1823) and Harpagus bidentatus (Double-toothed Kite) (Latham, 1790), respectively. This strategy was not observed in Jacana jacana from the current survey.

The fact that depth did not influence the distribution of the foraging Wattled Jacana corroborates the ideas of other authors (Sick, 1997; Antas, 2004; Nunes and Piratelli, 2005; Sigrist, 2006) who mention that these birds are able to move over the floating vegetation in search of food because of the unique morphology of their tarsus and phalanges, thus having no major limitations of foraging sites. Therefore, the depth was not an important factor to explain the distribution of foragers. This same skill and morphology does not occur among water gallinules (Porphyrula sp.), that have difficulty crossing extremely tangled environments (Sick, 1997).

If we consider the occurrence of foraging individuals with regard to edge distance, we must once again reflect on the ability this species has to walk on the macrophyte banks so that we do not assume that the greater the distance from the edge, the greater the depth of the lake. The Pantanal is a floodplain without any great altitudinal variation to warrant such a relationship (Antas, 2004). That said, there may be variations in the spatial distribution of the macrophyte bank, since the plants may become more agglomerated in the regions closer to the margin. Thus, it seems that what characterizes the distribution of foragers on feeding habitats is not the distance from the edge and the depth, but possibly the presence of aquatic plants clustered along the banks of the swamps (Moreno et al., 2005). In any case, this idea has yet to be tested following a specific protocol and considering the factors raised above, to assess habitat selection by foraging.

Although many ornithologists accept the idea that birds are, in general, more active in the early morning (Land, 1963; Leck, 1969; Sick, 1997), we found no significant difference in the abundance of foragers throughout the day. This result suggests that, during foraging, individuals possibly do not experience remarkable effects from the variation in temperature and humidity throughout the day. However, one can expect that the foraging activity and behavior are influenced by the structural characteristics of the habitat rather than by the time of day (Kantak 1981). Nevertheless, more observations considering the seasonal changes on Pantanal landscape may reveal if this is a species pattern or an environment-dependent pattern.

Despite the conclusions about prey-capture efficiency in Wattled Jacana foragers, more detailed research focusing on factors that have not been analyzed such as food availability, presence of competitors and predators, is essential for revealing the main factors of the spatial and temporal distribution of the Wattled Jacana in an environment as extraordinary as the Pantanal. In addition, it would be essential to compare the diet composition between juveniles and adults trying to show if the preycapture efficiency corroborates with ability in acquisition of quality food and not only quantity.

Acknowledgements - We would like to thank Prof. Charles Duca, Miguel Angelo Marini, Joao Batista de Pinho and Eduardo Bessa for suggestions and criticisms to this manuscript. We would also like to thank the Núcleo de Estudos Ecológicos do Pantanal/UFMT/Ministério de Ciências e Tecnologia and Coordenação de Aperfeiçoamento de Pessoal de Nível Superior (Capes) for granting scholarships to these authors and the Universidade Federal de Mato Grosso for financial support.

\section{References}

ANTAS, PTZ., 2004. Pantanal - Guia de Aves. Rio de Janeiro: SESC, Departamento Nacional. 246 p. 
AZEVEDO, MAG. and DI-BERNARDO, M., 2005. História natural e conservação do gavião-tesoura, Elanoides forficatus, na Ilha de Santa Catarina, sul do Brasil. Revista Brasileira de Ornitologia, vol. 13, p. 81-88.

AZEVEDO, MAG., PIACENTINI, VQ., GHIZONI, IR., ALBUQUERQUE, JLB., SILVA, ES., JOENCK, CM., LIMA, AM. and ZÍLIO, F., 2006. Biologia do gavião-bombachinha, Harpagus diodon, no estado de Santa Catarina, sul do Brasil. Revista Brasileira de Ornitologia, vol. 14, no. 4, p. 351-357.

BURGER J. and GOCHFELD, M., 1983. Feeding behavior in Laughing Gulls: compensatory site selection by young. Condor, vol. 85, p. 467-473. http://dx.doi.org/10.2307/1367989

CLARK, CW. and MANGEL, M., 1986. The Evolutionary Advantages of Group Foraging. Theoretical Population Biology, vol. 30, no. 1, p. 45-75. http://dx.doi.org/10.1016/00405809(86)90024-9

EMLEN, ST. and WREGE, PH., 2004a. Division of labour in parental care behaviour of a sex-role-reversed shorebird, the Wattled jacana. Animal Behaviour, vol. 68, p. 847-855. http:// dx.doi.org/10.1016/j.anbehav.2003.08.034

-, 2004b. Size dimorphism, intrasexual competition, and sexual selection in Wattled Jacana (Jacana jacana), a sex-role-reversed shorebird in Panama. The Auk, vol. 121, no. 2, p. 391-403. http:// dx.doi.org/10.1642/0004-8038(2004)121[0391:SDICAS]2.0.CO;2

FERREIRA, I., 1984. Comportamento reprodutivo da Jaçana, Jacana jacana (L.,1766) (Aves, Charadriiformes, Jacanidae) no Estado do Rio de Janeiro. Rio de Janeiro: Universidade Federal do Rio de Janeiro. Dissertação de Mestrado em Zoologia.

KANTAK, GE., 1981. Temporal feeding patterns of some tropical frugivores. Condor, vol. 83, p. 185-187. http://dx.doi. org/10.2307/1367429

LAND, HC., 1963. A tropical feeding tree. The Wilson Bulletin, vol. 75 , p. 199-200.

LECK, CF., 1969. Observations of birds exploiting a Central America fruit tree. The Wilson Bulletin, vol. 81, no. 3, p. 264-269.

LIMA, PC., LIMA NETO, TNCL. and SILVA, LE., 2008. Primeiro registro documentado da reprodução do João-chique-chique (Gyalophylax hellmayri Reiser, 1905) na pátria da Anadorhynchus leari. Atualidades Ornitológicas, vol. 144, p. 33-35.

MACARTHUR, RH. and PIANKA, ER., 1966. On optimal use of a patchy environment. American Naturalist, vol. 100, p. 603-609.

MARTINS, FC. and DONATELLI, RJ., 2001. Estratégia alimentar de Guira guira (Cuculidae, Crotophaginae) na região centro-oeste do Estado de São Paulo. Revista Brasileira de Ornitologia, vol. 9, no. 2, p. 89-94.
MORENO, AB., LAGOS, AR. and ALVES, MAS., 2005. Water depth selection during foraging and efficiency in prey capture by the egrets Casmerodius albus and Egretta thula (Aves, Ardeidae) in an urban lagoon in Rio de Janeiro State, Brazil. Iheringia, Série Zoológica, vol. 95, no. 1, p. 107-109.

MORRISON, ML., SLACK, R. and SHANLEY, JRE., 1978. Age and foraging ability relationships of Olivaceous Cormorants. The Wilson Bulletin, vol. 90, no. 3, p. 414-422.

NUNES, AP. and PIRATELLI, A., 2005. Comportamento da jaçanã (Jacana jacana Linnaeus, 1766) (Charadriiformes, Jacanidae) em uma lagoa urbana no município de Três Lagoas, Mato Grosso do Sul, Brasil. Atualidades Ornitológicas, vol. 126, p. 1-17.

REMSEN, JV. and ROBINSON, SK., 1990. A classification scheme for foraging behavior of birds in terrestrial habitats. In MORRISON, ML., RALPH, CJ., VERNER, J. and JEHL JUNIOR, JR. Avian foraging: theory, methodology and application. Lawrence: Cooper Ornithological Society (Studies in Avian Biology 13). p.144-160.

ROBINSON, SK. and HOLMES, RT., 1982. Foraging behaviour of forest birds: the relationships among search tactics, diet, and habitat structure. Ecology, vol. 63, no. 6, p. 1918-1931. http:// dx.doi.org/10.2307/1940130

SCOTT, DW., 1979. On optimal and data based histograms. Biometrika, vol. 66, no. 3, p. 605-610. http://dx.doi.org/10.1093/ biomet/66.3.605

SICK, H., 1997. Ornitologia Brasileira. Editora Nova Fronteira. Rio de Janeiro. 912 p.

SIGRIST, T., 2006. Aves do Brasil: uma visão artística. Editora Fosfértil. São Paulo. 672 p.

STEVENS, J., 1985. Foraging success of adult and juvenile Starlings Sturnus vulgaris: a tentative explanation for the preference of juveniles for cherries. The Ibis, vol. 127, p. 341-347. http:// dx.doi.org/10.1111/j.1474-919X.1985.tb05075.x

STOTZ, DF., FITZPATRICK, JW., PARKER III, TA. and MOSKOVITS, DK., 1996. Neotropical birds, ecology and conservation. Chicago; London: The University of Chicago Press. 479 p.

VALLE, AL., 2006. Eficiência e uso de área para captura de presas por golfinhos Sotalia fluviatilis: comparação entre adultos e juvenis. Acta Biológica Leopoldensia, vol. 28, no. 1, p. 55-60.

VANDERHOFF, EN. and EASON, PK., 2008. Comparisons between Juvenile and Adult American Robins Foraging for Mulberry Fruit. The Wilson Bulletin, vol. 120, no. 1, p. 209-213.

WERNER, EE. and GILLIAM, JF., 1984. The ontogenetic niche and species interactions in size-structured populations. Annиal Review of Ecology and Systematics, vol. 15, p. 393-425. http:// dx.doi.org/10.1146/annurev.es.15.110184.002141 
